\title{
SOME OBSERVATIONS OF THE KNOT ON OLD WIVES AND LAST MOUNTAIN LAKES
}

by Fred G. Bard and Fred W. Lahrman, Saskatchewan Museum of Natural History

The articles by Martin K. McNicholl (Blue Jay, 27:28-35; 83; 147-8) referring to prairie records of the Knot (Calidris canutus) have prompted us to submit some further observations of this bird. It is of interest, first of all, that the Saskatchewan Museum of Natural History has a number of specimens taken at Last Mountain and Old Wives Lakes (see Table 1).

Table 1. SMNH specimens of Knot taken at Last Mountain and Old Wives Lakes.

\begin{tabular}{lcr} 
Place taken & Date taken & Spec. No. \\
\hline Last Mountain Lake (Imperial Beach) & May 27, 1924 & $\# 1623$ \\
Last Mountain Lake (Imperial Beach) & May 18, 1949 & $\# 5073$ \\
Last Mountain Lake (Imperial Beach) & May 20, 1949 & $\# 5081$ \\
Last Mountain Lake (Imperial Beach) & May 20, 1949 & $\# 5084$ \\
$\quad$ (several flocks of 30 seen) & May 23, 1949 & \\
Last Mountain Lake (Imperial Beach) & May 23, 1949 & $\# 5374$ \\
Last Mountain Lake (Imperial Beach) & May 27, 1949 & $\# 4997$ \\
Last Mountain Lake (Imperial Beach) & May 23, 1925 & $\# 1783$ \\
Old Wives Lake & May 23, 1925 & $\# 1785$ \\
Old Wives Lake & May 31, 1925 & $\# 1784$ \\
Old Wives Lake & May
\end{tabular}

As shown in the table, the birds collected at Last Mountain Lake for the Museum were taken at Imperial Beach. During the period from May 19 to May 27, 1949, when we were collecting specimens there, flocks of Knots were observed regularly and we found them to be more plentiful than the Ruddy Turnstones. On May 30, however, Lahrman observed only two Knots, although the last of the Blackbellied Plovers did not depart until June 5 (when two flocks of approximately 30 birds each were observed flying northwest).

On May 22, 1952, on the easit shore of Last Mountain Lake, west of Govan, Lahrman found Knots and Ruddy Turnstones to be very plentiful. Here during the following years he observed Knots on different occasions during the latter part of May. On May 27, 1969, while photographing shorebirds near Imperial Beach, he obtained several photos of Knots, at which time several small flocks of three to six individuals, and two or three singles were noted.

On the shores of Last Mountain
Lake we have seen Knots only near Valeport, Govan and Imperial Beach, and only during the spring migration period. The Knot appears to be a fairly common spring migrant here.

On May 27, 1969, when Lahrman was photographing Knots at Last Mountain Lake, Bard observed eight Knots near the cutbanks on Old Wives Lake. Several shorebirds were seen feeding along the shore, too far out for the $8 \times 40$ binoculars, but with the tripod and $20 \mathrm{X}$ scope each bird could be observed and identified (except for the confusing "peeps"). Watching the Knots in this location recalled several specimens that had been taken for the Chicago Museum in this area by Ashley Hines. Two of our SMNH specimens from this area were taken by Hugh McCrae of Crestwynd.

We have found the Knot to prefer the open, sandy or rocky points which jut out into the lake (particularly at Last Mountain Lake), and we note that they are often seen with Sanderlings, Ruddy Turnstones and Blackbellied Plovers, although larger flocks of Knots tend to keep to themselves. 